\title{
LA IDENTIDAD GÓTICA Y LA LÓGICA DE MERCADO EN San Cristóbal de Las Casas, Chiapas
}

\author{
Luis Fernando Bolaños Gordillo
}

Resumen: Los góticos tienen algo de melómanos, cinéfilos, amantes del arte y asumen formar parte de la tribu urbana más librepensadora. Este artículo analiza cómo, a pesar de sus posiciones críticas ante la familia, el gobierno, las religiones o los medios masivos, así como pese a la elaboración de un discurso de corte autónomo e individualista, el movimiento gótico no escapa a la lógica del mercado. También se verá que existen cierto tipo de productos entre vestimenta, accesorios, maquillaje, libros, discos, cinematografía de terror, entre otros, que circulan en el "mercado oscuro" con la bandera de la alternatividad, y que homogeneizan sus comportamientos de consumo. El análisis aborda cómo este movimiento de corte autónomo se fue transformando en una moda que instituyó cierto tipo de ideas ligadas a patrones de consumo.

Palabras clave: Música gótica, industrias culturales mercadotecnia, patrones de consumo.

Enviado a dictamen: 03 de mayo de 2012

Aprobación: 01 de junuo de 2012

Revisiones: 2

Dr. Luis Fernando Bolaños Gordillo. Doctor en Ciencias Sociales por el Centro de Estudios Superiores de México y Centroamérica de la Universidad de Ciencias y Artes de Chiapas. Profesor de Tiempo Completode la Licenciatura en Comunicación Intercultural de la Universidad Intercultural de Chiapas. Temas de especialización: Cultura de masas, tribus urbanas e identidades. Correo electrónico: fernandog7007@hotmail.com.
Abstract: Goths have something for music lovers, lovers, lovers of art, and they assume to be part of the most Freethought urban tribe. This article analyzes despite their critical positions to the family, the Government, religions or mass media as well as the development of a discourse of court autonomous and individualistic, the Gothic movement does not escape the logic of market and that there are certain types of products between clothing, accessories, make-up, books, discs, cinematography of terror, including circulating in the 'dark market' with the flag of alternatividad They homogeneizan their consumption behaviors. The analysis deals with how this movement of autonomous Court was transformed in a fashion which instituted certain kinds of ideas related to consumption patterns.

Keywords: Gothic music, cultural industries, marketing, patterns of consumption.

\section{¿Quiénes son los góticos?}

E n este artículo planteo algunos rasgos que nos muestran el corte autónomo de la cultura gótica en San Cristóbal de Las Casas, Chiapas. Entre otros, el cultivodelainteligencia, la voluntad, el aislamiento creativo, su crítica voraz hacia un sistema considerado decadente que, sin embargo, no escapa a la lógica del mercado, dado que adquieren ciertos artículos que reafirman su identidad. 
Para tal efecto hago, en primer lugar, una descripción de los estilos de vida que tienen estos jóvenes, su identificación con el dolor, la muerte y el diablo, para ir analizando después cómo todo esto influye en la asunción de una identidad en resistencia ante todo rasgo de hegemonía. Posteriormente, hago un análisis donde se contraponen el sentido de autonomía y libertad de estos jóvenes con sus patrones de consumo.

Para elaborar este artículo realicé entrevistas en profundidad con jóvenes que se reconocen de esta cultura en San Cristóbal de Las Casas, Chiapas, entre el 2008 y el 2010, donde abordé temas relacionados con sus preferencias discográficas, literarias, cinematográficas y cibernéticas, así como su adquisición de cierto tipo de productos - como vestimenta y accesorios- que forman parte de su identidad.

Desde una mirada superficial los góticos podrían ser simplemente jóvenes que visten totalmente de color negro, que tienen una visión pesimista de la vida, la sociedad y sus instituciones, que gustan de géneros musicales como el black metal y que se identifican con diversas corrientes ocultistas, algunas de ellas simpatizantes del satanismo moderno.

Los góticos son la tribu urbana más producida estéticamente; sus miembros se visten completamente de negro, y de ese color, dicen, es la visión que tienen del mundo: desencantada y esencialmente pesimista (Molina, 2009: 154).

Sin embargo, la elaboración de esta identidad tiene matices autónomos muy significativos, en los cuales se manifiesta el cultivo de la inteligencia y de la voluntad, donde el arte (principalmente la música) es la puerta a lo que se podría denominar el lado oscuro de la cultura, aquel que la parte instituyente define como "contracultura".

Los góticos se asumen como actores dionisiacos de una trama siniestra inserta en las contradicciones de la vida social en la que elaboran, con base en sus historias de vida - muy vinculadas al dolor-, visiones trágicas y nihilistas en las que no hay futuro, transmitidas a través de poemas, canciones, dibujos, pinturas, animaciones, etcétera, fruto de lo que ellos denominan el aislamiento creativo.

Laidentidadgóticaesuna sumade auto-determinismo, individualismo, narcisismo, afición por el pasado, gusto por el arte y simpatía por lo sobrenatural, producto de un proceso de autodescubrimiento constante que se nutre de las ideas y de las manifestaciones artísticas más extremas de diversas épocas y contextos. Detrás de cada gótico podrían advertirse las ideas del Marqués de Sade, Charles Baudelaire, Sheridan Le Fanu, Oscar Wilde, entre otros, que plasmaron en sus obras su propia visión de la sociedad de su tiempo.

Los góticos intentan expresarse, aunque no son entendidos en una sociedad en donde el negro es el color del luto y la muerte, y no tiene una parte bella. Adoran y practican cualquier forma de arte y se identifican con los sentimientos que expresan las canciones de sus ídolos. Saben que no pueden cambiar al mundo y por eso no lo intentan. ${ }^{1}$

Es evidente la percepción de que aquello que no pueden encontrar en este mundo está en el más allá, aunque este "más allá" podría ser metáfora de un contexto alternativo que les permite crear y expresar cosas distintas. Podría pensarse que ser gótico es sinónimo de ser malvado o perverso, pero esa manera de ser es para ellos el punto de partida desde el cual reflexionar sobre las complejidades de la sociedad en la que viven y sobre la condición humana, valiéndose para ello de la música, la cinematografía de terror y obras como El Anticristo o Así hablaba Zaratustra, de Friedrich Nietzsche.

Estos jóvenes, a la par que van elaborando una imagen siniestra, un pensamiento disidente y algunas posiciones narcisistas, se distancian de las normas que consideran limitantes del libre pensamiento y les 
impiden incursionar en su propio yo, fortaleciendo una identidad introvertida, nihilista y selectiva, con un marcado sentido de superioridad intelectual ante los que consideran débiles o mediocres, a quienes suelen ridiculizar sutilmente.

Gótico. Esta palabra designa algo más que una joven subcultura, una tribu urbana, una estética siniestra o un género literario. Alude también a un enfoque filosófico (una "visión del mundo", según dijo el novelista irlandés J, Sheridan La Fanu, en su libro Las criaturas del espejo); es el cosmos en negativo, invertido (lo extraño y espeluznante son sólo lugares comunes, mientras que el día a día es algo en verdad misterioso y extraordinario). Aquílo oscuroy lo amenazador poseen un irresistible encanto, mientras que la normalidad y la vida acomodada sólo prometen hastío y decadencia (Fuentes, 2007: 11).

Como se verá más adelante, pese a su marcado sentido autónomo existe un factor mercantilista alimentado por publicaciones especializadas como la revista Gótica Life in Darkness² (México) o bien por críticos internacionales de música o cinematografía, quienes informan constantemente sobre las tendencias y productos que deben adquirir quienes estén dentro de este movimiento.

\section{Una tribu auto-determinista en un mundo de industrias culturales}

Los góticos se asumen como seres que cultivan la autonomía, la inteligencia y la voluntad, y esta autoafirmación está influida por el pensamiento de Friedrich Nietzsche. Ellos se consideran "superhombres" y "supermujeres" que buscan instalarse por encima de la masa y de lo que consideran políticamente correcto, aquello que subsume el pensamiento. Para tal efecto elaboran formas de pensar, discursos, actitudes y creaciones artísticas, con una combinación autónoma, crítica y pesimista ante instancias como la familia, la religión, el gobierno o los medios de comunicación.

En su crítica hacia los valores establecidos socialmente de forma unilateral y ante la imposibilidad de que alguna instancia les garantice medios y espacios de expresión, los góticos elaboran discursos, acciones y eventos que describen su sentido de marginalización y el carácter reivindicativo de lo que denominan "el lado oscuro de la cultura". La gran mayoría no se atreve reconocer esto en sí mismo o incursionar en ello por considerarlo prohibido: un gótico se distingue por no auto-limitarse (ver figura 1 ).

Lo gótico puede definirse como una identidad en resistencia no violenta, que tiene posiciones radicales ante diversas instancias y que delimita sus fronteras culturales con otros movimientos considerados como obedientes al sistema. Estos jóvenes construyen su propio mundo y se oponen en sus discursos al consumismo fomentado por el capitalismo moderno, aunque esto se cuestionará más adelante.

Este sentido autónomo está influido también por las literaturas romántica, decadente y el bohemianismo, e intenta corresponder a una visión nihilista de la condición humana que está llena de dolor, miedo, angustia y terror. Esta tribu urbana enaltece el reconocimiento de un sí mismo oscuro y ácido que forma parte de un mundo subterráneo (pero no subalterno) donde establecen posiciones muy puntuales entre la autonomía y los determinismos sociales.

Su manera de mostrar rechazo a la sociedad no es violenta sino pasiva, a través de su atuendo y su actitud luctuosa. Son individualistas, tienden al disfrute de la creación artística y el intelecto (Escribano y Carrera, 2007: 89).

El lado oscuro de la cultura es el referente desde el cual se deslindan de todo rasgo totalitario, de cualquier medio o estrategia de hegemonía social y de normas consideradas como ataduras para lo que creen auténtico, lo que no es apto para las masas. Ellos no intentan cambiar a la sociedad, sino edificar su propio espacio - 
invisible pero poderoso - con sus particulares medios de expresión.

Escribano y Carrera (2007: 77) afirman que es el interés por la cultura lo que caracteriza a estos jóvenes: conocen el cine, la música, las bellas artes en general y la literatura en particular. Estos jóvenes prefieren manifestaciones artísticas que, bajo toda una gama de simbologías relacionadas con el dolor, la muerte, lo macabro, lo sobrenatural, lo apolítico o lo satánico, les brinde referentes tanto para conocerse y auto-liberarse a sí mismos como para cuestionar la sociedad en la que viven.

El dolor proporciona a estos jóvenes diversos sentidos a sus percepciones de la complejidad de la existencia y de la condición humana, da cuenta de sus experiencias en la vida e influye en su manera de expresarse y relacionarse con los demás. El dolor podría tomarse en primera instancia como el resultado de la falta de sentido de la vida, pero son los significados personales acerca del dolor lo que les proporciona tal. El dolor es una forma de representarse a sí mismos y a los demás, a quienes generalmente consideran superficiales e inferiores intelectualmente. El dolor se constituye como una forma de coronar su nostalgia (Bolaños, 2011: 30).

En sus discursos establecen críticas y posiciones muy puntuales contra todo aquello que impide a las personas convertirse en sujetos librepensadores y se valen principalmente del arte y de la comunicación alternativa para compartir su desolada percepción de la existencia y difundir los eventos donde comparten sus creaciones (ver figura 2).

En su constante proceso de autodescubrimiento, los góticos se van distanciando de otras personas que consideran que suprimen sus deseos, sus pasiones, su voluntad, su capacidad de crear o que marchitan su inteligencia.Edifican sus propios espacios alrededor de ideales como la trascendencia personal, el ensalzamiento de las pasiones, la creación sin límites y el ejercicio de la voluntad - tal y como lo hacen de su particular interpretación de Nietzsche- para construir al "superhombre" o "supermujer" que superará los vacíos que la sociedad ha creado. Lo gótico podría verse como la recuperación del tiempo en que no se pertenecieron a sí mismos.

Basándome en Umberto Eco, en Apocalípticos e Integrados (1995), estos jóvenes pueden verse en el ámbito de los "apocalípticos", una comunidad de "superhombres", que buscan elevarse por encima de la banalidad media, aquellos que se consideran que no están instalados en el ámbito de la masa, porque han roto con todo aquello que se considera instituido de manera homogénea (Bolaños, 2011:17).

Norma Díaz García ${ }^{4}$ precisó que los góticos no se conforman con lo que transmiten los medios convencionales porque no estimulan la crítica o el libre pensamiento, sino que buscan en otras instancias no convencionales, como el legado de los poetas malditos o, aún más extremas, como el satanismo, donde encuentran muchos elementos que alimentan su autonomía.

Los góticos afirman que están vivos (una alusión al uso de la inteligencia y de la voluntad), en una instancia paralela a una sociedad considerada como muerta: ellos son los no-muertos. Esto explica la metáfora extraída de la literatura vampírica: están vivos mientras que los que no ejercen su autonomía están muertos, están integrados, son obedientes.

Iván Darío Bonifaz Hernández ${ }^{5}$ compara a la sociedad muerta en vida con los zombies, sus personajes de terror favoritos, y explica que la mayor parte de las personas deambulan por la vida sin detenerse a pensar por qué actúan de cierta forma, por qué consumen determinados productos que no necesitan o por qué siguen al pie de la letra las normas aún a costa de sacrificar su felicidad. "El ser humano es un zombie que estando muerto destruye a los demás”, ironizó. 
Estos jóvenes son nihilistas pero reconocen que su futuro lo construyen con el pasado: evocan elementos románticos, decadentes, terroríficos o sobrenaturales, para fijar su posición ante diversas instancias. La historia y la cultura juegan un papel fundamental en este proceso de auto-reconstrucción y auto-liberación, porque es ahí donde se manifiestan las visiones oscuras que tuvieron sus autores preferidos en sus respectivas épocas.

En sus creaciones los góticos se asumen como "románticos extremos", "hijos de la noche", "amantes de la oscuridad", "decadentes", "herederos de los poetas malditos" y, en síntesis, como parte de un mundo distinto en el que la oscuridad, el dolor, el diablo y la muerte, son los principales símbolos en la elaboración de sus ideas.

Un poema escrito por Norma Díaz García ilustra esta forma de pensar:

Por mucho tiempo vagué en la obscuridad sola, y sin algún fantasma guía,

jamás necesité de compañía,

mi pasado me cubría.

Caminé por mucho tiempo por el inframundo equivocado,

y nadie me decía nada, inclusive me guiaban más a la devastación.

Toda mi vida era un desastre, no tenía sentido, mi razón, todo estaba de cabeza y sólo tenía un color.

Nada sistematizaba en mi cabeza y no me importaba

más el dolor.

La identidad gótica es una instancia que se cierra sobre sí misma y pone en evidencia la falta de espacios y medios de expresión para los jóvenes. Estamos ante un proceso permanente de auto-transformación donde la libertad de crear, de expresarse y de ser, son los puntos de partida para auto-determinarse. Lo gótico es una eliminación del sentido de la masa alentado por los pensamientos críticos más radicales de diversas épocas, es una reelaboración de las formas de desenvolverse en sociedad, una reflexión permanente sobre lo que implica la identidad. Lo oscuro es permanente, coinciden y, quien no comprenda esto, es un farsante, un posser atrapado por las modas y las tendencias que imponen los medios.

En la creación de sus espacios de expresión, algunos de estos jóvenes relacionan estrechamente su sentido autónomo y sus procesos creativos con la figura de Satán ${ }^{7}$, una imagen emblemática que les significa rebeldía, irreverencia e inteligencia frente a un dios percibido como hegemónico.

Este distanciamiento es en realidad la reactivación del instinto vital de preservación, de conservación en el ser; es la figura demoníaca que encontramos en todos los mitos y todas las religiones; el Satán de la tradición bíblica que dice no a la sumisión (Mafessoli, 2007: 111).

Lo satánico, simbólicamente hablando, brinda a estos jóvenes elementos para construir espacios muy selectos donde pueden tener mayor libertad de expresión o creación, porque la figura del maligno les significa precisamente eso: en el lado oscuro de la cultura se perciben solos y distintos y, por lo tanto, con mayores posibilidades de explorar y crear sin cortapisas. El famoso axioma de Crowley, "haz todo lo que quieras, esa ha de ser la Ley", explica este tipo de actitudes.

Para Carlos Arboleda Mora, ${ }^{9}$ existe un satanismo racionalista propio de personas cultivadas intelectualmente, que generalmente han leído obras de Freidrich Nietzsche y Aleister Crowley. Este satanismo es fruto de una opción personal y de una filosofía de vida que puede definirse como formas particulares de rechazar cierto tipo de valores y verdades únicas.

Su interpretación de la figura del maligno está muy vinculada con el género Black Metal (ver figura 3) 
cuyas letras son oscuras, amenazantes, degradantes, decadentes y maléficas: no hay final feliz, es el nihilismo llevado al máximo. Este género proporciona a los góticos temas que difícilmente serían tratados desde una perspectiva tradicional o comercial: el satanismo ritual, la necrofilia, el vampirismo y otros aspectos relacionados con la oscuridad tanto sobrenatural (esotéricamente hablando) como meramente humana. En el género black metal se puede encontrar este tipo de ideas:

Negra es la noche, por el metal luchamos

Amplis ${ }^{10}$ listos para explotar

Gritos de energía, magia y sueños

Satanás grabó la primera nota.

Sonamos la campana del caos e infierno

Metal para auténticos maníacos.

Rápida fusión de acero, fortuna sobre ruedas

Hemorragia cerebral es la cura

Por el metal negro

Entrega tu alma a los dioses del rock n 'rolll'

Su sentido autónomo combinado con elementos ocultistas se yergue como una forma de asumir la autenticidad, una manera de no negarse a sí mismos, un espejo para vivir de manera distinta de los cánones tradicionales. El ideal de muerte y dolor está intimamente ligado al de la trascendencia personal, y simboliza dar paso a nuevas ideas y actitudes no convencionales.

\section{El auto-determinismo: entre el consumo y el consumismo}

Pese a la insistencia de los sentidos autónomo y alternativo, este movimiento, tanto en ideas como en imagen, ha sido bien aprovechado por las industrias culturales para posicionar diferentes tipos de productos que generan demandas identitarias. Hay un gran mercado oscuro que lleva aproximadamente treinta años de existencia en México y unos diez en San Cristóbal de Las Casas, que satisface necesidades discográficas, literarias, cinematográficas, de vestimenta y de accesorios de estos jóvenes.

La lógica del mercado retoma los elementos que dan sentido a la identidad gótica: la muerte, el diablo, los vampiros o los monstruos. Los significados que se le dan a la noche, a la oscuridad, la decadencia o al dolor, sirven para posicionar eficazmente toda una gama de productos que se erigen como distintivos del movimiento y que circulan en diversos medios. Un disco de Christian Dead, ${ }^{12}$ por ejemplo, se puede adquirir por intercambio en tianguis o en franquicias como Mix Up o Cultura del Rock.

Lo gótico, al igual que el rock, tiene un doble carácter: fomenta actitudes autónomas pero no escapa a la cultura de masas como objeto de consumo; rompe con ciertos patrones sociales pero instituye otros estereotipos a seguir.

En ese sentido, el doble carácter del rock nos permite relevar la estrecha relación de los productos rockeros (y el conjunto de los productores de los mismos) con universos culturales juveniles diversos y diferenciados entre sí. Caracterización que hace posible ampliar los límites del campo cultural y ubicar a los agentes del campo rockero en una tensión permanente por satisfacer: los intereses mercantilistas de las industrias discográficas, las demandas (emocionales, existenciales, musicales) y utopías de sus auditorios y los propios intereses de los músicos rockeros (Urteaga, 1998: 26).

Onésimo Guzmán Arias, sostiene que para ser gótico hay que ser melómano y, por lo tanto, hay que tener dinero para adquirir discografía. "La mayoría puede tener por ahí una que otra joyita discográfica clásica del movimiento", apuntó. Existe una cuestión de prestigio en este aspecto dado el egocentrismo que prevalece en estos jóvenes y la necesidad de que los productos 
adquiridos sean "auténticos" o "gruesos", es decir, lo que un ciudadano común no compraría.

La adoración de la oscuridad, la depresión como estado de ánimo del que se puede disfrutar, la soledad o el aislamiento provocado, y el gusto por las formas consideradas repulsivas, dan forma a una estética que presentada de esta manera se opone a lo que consideramos como apto para las masas (Fuentes, 2007: 107)

En San Cristóbal de Las Casas existe una tienda llamada Underground Empire, ubicada en el interior de la Plaza Mazariegos, en la que se exhiben capas vampirescas, botas de plataforma alta adornadas con motivos plateados, personajes en miniaturas de cantantes de diversos grupos de heavy metal, ropa interior de piel negra (vinculada al aspecto sadomasoquista del movimiento), música en general (calificada como de culto), imágenes de zombies de diferentes tamaños, literatura y, en síntesis, todo lo que necesita un joven para asumirse y verse como un gótico auténtico.

Índira Isis Sánchez Navarrete,${ }^{13}$ encargada de esta tienda, sostuvo que un gótico en toda la extensión de la palabra sabe distinguir entre el sentido superficial del movimiento y la parte más "densa", la más "gruesa", la que "pocos conocen", cuya diferencia la marca el grado de inserción en la literatura, que se constituye como uno de los elementos que permiten a estos jóvenes "neutralizar" estos embates capitalistas y volverse selectivos con lo que leen o escuchan. Agregó que este proceso de madurez puede llevar muchos años.

Dijo que, como encargada de la tienda, ha conocido a muchos jóvenes que llegan atraídos por el movimiento oscuro, pero que poco o nada conocen de su literatura o discografía gótica. Subrayó que esto es normal en la etapa incipiente, cuando comienzan a construir su personalidad oscura, pero agregó que hay quienes, a pesar de estar mucho tiempo en el movimiento, siguen adquiriendo materiales que no son distintivos de la cultura oscura y consumen lo que ven en la publicidad.

"En los estantes aún están algunas obras literarias que se adquirieron años atrás y ahí siguen", dijo al referirse a que muchos jóvenes van más por muñecos de colección o accesorios. Sobre la discografía apuntó que "un jovencito podría tener en sus manos una verdadera joya gótica y no darse cuenta, dejarla donde la encontró".

Sobre la relación entre producto y mercado Zygmunt Bauman apunta:

Ellos son, simultáneamente, los promotores del producto y el producto que promueven. Son, al mismo tiempo, encargado de marketing y mercadería, vendedor ambulante y artículo en venta. Más allá del casillero al que los confinen quienes confeccionan las estadísticas, todos ellos son habitantes del mismo espacio social conocido con el nombre de mercado (Bauman, 2007: 17 y 18).

Según Onésimo Guzmán Arias un gótico sabe distinguir a grupos que poco o nada tienen que ver con el sentido oscuro. Sostuvo que un gótico dedica muchas horas a escuchar música alternativa y a leer novelas románticas, así como a ver cinematografía de terror. La música, puntualizó, tiene un papel muy importante para tomar una posición crítica ante determinados acontecimientos ya que les brinda ideas sobre diferentes épocas y contextos, aunque reconoció que no todos asumen esta actitud y caen en el consumismo.

Puso de manifiesto que la inteligencia del gótico le proporciona un "consumo inteligente" que le permite adquirir cierto tipo de productos del mercado oscuro sin que se sientan alienados. Esto ocasiona un doble sentido de la alternatividad en el movimiento: primero ante lo que consideran comercial y, luego, ante lo que consideran como productos "intrusos" en su identidad. Agregó que hay jóvenes que se creen góticos por comprar un disco de "My Chemical Romance", pero que en realidad este grupo es distintivo de los emos. "Nos 
gusta el dolor pero no somos iguales", dijo al establecer la distinción entre ambas tribus urbanas.

Los elementos distintivos de la cultura gótica han sido aprovechados y re-significados con el apoyo de los medios audiovisuales para posicionar productos que se adquieren como símbolos de poder y disidencia: un gótico puede sentirse parte de una hueste de seres oscuros, identificarse con el Anticristo o con los poetas malditos pero, al fin y al cabo, gasta una buena cantidad de dinero para mantener su estatus y prestigio dentro del movimiento.

Ante esto, Iván Darío Bonifaz Hernández, afirmó que una cosa es ser consumidor y otra consumista. El primero, sostuvo, sabe de antemano cuáles son los elementos distintivos de su identidad y el segundo, es un alienado que cree que comprando va fortaleciendo su imagen y su prestigio como ser oscuro.

Zygmunt Bauman (2007) señala que el consumo es un rasgo y una ocupación del individuo y el consumismo es un atributo de la sociedad. Entonces, si estos jóvenes afirman cultivar la inteligencia como un atributo individual, su consumo busca hacerlo también, es decir, su adquisición de productos busca tener un enfoque inteligente que les aleje de todo rasgo de alienación.

De esta manera, el mercado oscuro es un universo donde los atributos de los antihéroes románticos, por ejemplo, suelen materializarse en forma de productos que generan modas y tendencias adquiridas por ciertos jóvenes que se identifican entre sí mediante imágenes distintivas. La novela de Ann Rice, Entrevista con el Vampiro, desató un boom de estos personajes a principios de los años noventa y la reciente saga Crepúsculo provocó una identificación de los adolescentes con la imagen poderosa, sensual, perversa y perfectamente estética de los vampiros, que generó jugosas ganancias (ver figura 4).

Para Norma Díaz García este tipo de producciones fomentan el deseo en los jóvenes: desean "convertirse en...", "parecerse a..." y esto se traduce en la adquisición de productos que generan gratificaciones que al poco tiempo pasan de moda. "Algunos son vampiros por un tiempo, luego les da por los fantasmas y no tienen una posición fija dentro del movimiento", apuntó, aunque esto se da más en los góticos incipientes. Ella dijo tener afición por coleccionar ataúdes de diferentes tamaños. "Tuve uno real pero no lo pude mantener en casa por presiones de mi familia", afirmó.

A pesar del discurso autónomo que estos jóvenes manifiestan en diversos medios, existen evidentes rasgos de alienación provocados por mecanismos sutiles mercadotécnicos. Si en sus discursos cotidianos sostienen que hay poetas, músicos o cineastas de culto, existe por supuesto un medio que propicia que se erijan como tales y que utiliza diversas estrategias para que las diversas colectividades se asuman como oscuras y relacionen sus elementos identitarios con los objetos que los vuelven concretos.

La homogeneización de las necesidades y de los comportamientos de consumo forma parte de las fuertes tendencias que caracterizan el nuevo ambiente internacional de la empresa (Augé, 2008:13).

Las películas y las imágenes de los cantantes o los integrantes de los grupos son fuente de creación del sentido icónico del movimiento. Estos jóvenes elaboran sus imágenes con los recursos que tienen a su alcance y van edificando así un collage que reúne elementos románticos, decadentes, bohemios, punks, beatniks, místicos, satánicos, entre otros, y cuya demanda tiene ofertas listas para ser satisfechas.
El "estilo consumista" pide que la satisfacción haya de ser, deba ser, es mejor que sea, instantánea, mientras que el valor exclusivo, el único "uso" de los objetos, es su capacidad para dar satisfacción (Bauman, 2007:137).

Lo sobrenatural fue aprovechado mercadotécnicamente para posicionar imágenes y atraer compradores potenciales, la mayoría jóvenes ávidos del mundo 
sobrenatural. Cantantes como Marylin Manson o grupos como Korn, representan muy bien este uso mercadotécnico para posicionar discos y otros productos relacionados con el movimiento oscuro que consumen actualmente millones de jóvenes maravillados por la oscuridad que creyendo ser góticos en toda la extensión de la palabra.

Estela Pérez Díaz ${ }^{14}$ sostiene que muchos jóvenes creen ser góticos simplemente porque les gusta el rock heavy metal o porque les atraen las películas de terror o el género gore. Afirma que esto es una confusión derivada del exceso de información existente en el mercado.

Así es muy difícil que un gótico incipiente, saturado de información y mercadotecnia, encuentre pronto la diferencia entre un grupo realmente gótico y uno que simplemente cubre los requisitos de imagen fijados desde las industrias culturales para formar parte del movimiento oscuro. Esto sería el resultado de horas de escuchar música durante años y sería también un asunto de recursos económicos, aunque internet ofrece infinidad de páginas donde se puede descargar música de forma gratuita.

Onésimo Guzmán Arias expone que resulta muy difícil para quienes se inician en el movimiento distinguir a los verdaderos grupos góticos ya que para ello hay que tener conocimientos musicales. Como la gran mayoría no los tienen, toman como gótico todo lo que se les ofrece. El informante acepta que pasó por este proceso.

Los canales de videos, las revistas especializadas de heavy rock (Metal Hammer, por ejemplo), las páginas de internet, radios comerciales y/o alternativas, películas de terror, entre otras, son las primeras fuentes de información con las que van elaborando este tipo de identidad. Todas ellas giran en torno a la música y la imagen oscura. No es lo mismo asumirse como gótico después de ver un canal de videos como MTV o Telehit (propiedad de Televisa), tras apreciar a Marylin Manson, que después de haberse devorado las obras románticas. Es muy distinto ser gótico que sentir atracción por la oscuridad, apunta Estela Pérez Díaz.

Sobre Marylin Manson (ver figura 5), un representante de este aspecto comercial, Onésimo Guzmán Arias, apunta: "Es un símbolo de todo lo irresponsablemente comercial, es la suma de muchos elementos ocultistas combinados con publicidad. El nombre de su primer disco lo evidencia así, Anticristo Superestrella, y él no obedece más que a intereses comerciales de manipular a las masas hacia un supuesto satanismo. El verdadero satanismo aquí es la publicidad sin escrúpulos".

Lo gótico no puede entenderse entonces sin un análisis del empuje de las industrias culturales que, a través de las innovaciones tecnológicas, están modificando los gustos y preferencias de estos jóvenes. El exceso de oferta de productos góticos podría influir para que los jóvenes sientan atracción por el lado oscuro y lo reafirmen adquiriendo cierto tipo de productos.

Desde hace mucho tiempo se observa que la tendencia a mercantilizar la producción cultural, masificar el arte y la literatura y ofrecer los bienes culturales por varios soportes a la vez (por ejemplo, el cine no sólo en salas sino en televisión y video), quita autonomía a los campos culturales (García Canclini, 2007: 27 y 28).

En tiendas como Mix Up se puede encontrar música y videos clasificados por temas. En los discos compactos existe una sección en la que se puede encontrar death goth, gore, trash, heavy, así como sus variantes tecno. En el área de videos existe una sección dedicada al terror. El disco de un grupo gótico verdadero se puede encontrar igualmente en "El Chopo" que en una tienda especializada, en páginas web y hasta en casas de venta de discos transnacionales.

Si lo gótico tiene demanda obviamente hay una oferta que la satisface. A la maquinaria que construye 
la oferta no le importa si el grupo es realmente gótico o no, su meta es vender millones de discos, playeras, videos, juguetes, gorras, posters y otros productos. Esto demuestra que lo que nace con un sentido de rebeldía, alternatividad o rechazo a las normas dominantes termina convirtiéndose en mercancía, en objeto de consumo.

Con su inagotable capacidad para idealizar ciegamente todo lo que es distinto, a la contracultura siempre le ha fascinado el exotismo (Heath Potter, 2005: 290).

Otro medio donde se presentan los referentes históricos góticos, pero rodeados por publicidad de productos alusivos, son las revistas que se editan en nuestro país desde el 2007. Por ejemplo, la revista Dark, Escena GothDeath Rock, cuenta con publicidad de bares góticos como el Dada X, así como de diversas tiendas que venden productos relacionados con el movimiento como Erética, Nosferatu Resurrection, Morty, Vissu Total, Dhampir y Moda alternativa. La tienda Erética vende playeras, sudaderas, botas, accesorios, discos y ofrece servicios de tatuaje y piercings (perforaciones). Ser gótico, entonces, es también un asunto de compra y ventay, por que no, de prestigio. "La rebeldía no supone una amenaza para el sistema, porque es el sistema" (Heath y Potter, 2005: 202).

\section{Consideraciones finales: del negro intenso al negro "light"}

La música, la literatura, la cinematografía y otras artes proporcionan a los góticos formas de acercarse a contextos en los que se pueden abordar temas que, difícilmente, serían tratados desde una perspectiva tradicional. Esto, que no escapa a un exotismo en el contexto de las industrias culturales, genera que el movimiento se vea atrapado en la lógica del mercado. El consumo cultural de estos jóvenes va ligado a su rechazo hacia todo aquello que impide a las personas convertirse en sujetos y, por eso, su adquisición de cierto tipo de productos se vincula con sus intereses, sus ideales y sus formas de ver las cosas.

Sin embargo, el sentido de autonomía de la identidad gótica es aprovechado por las industrias culturales para posicionar productos o imágenes que se relacionan estrechamente con las visiones que tienen de la decadencia y las contradicciones sociales. Al adquirir discografía, literatura o cinematografía, estos jóvenes tienen la convicción de que están deslindándose de toda forma totalitaria, de todo rasgo de hegemonía social y, obviamente, de productos creados para las masas.

A estos productos se les da las categorías de "gruesos", "ácidos", "malditos", "irreverentes" o de "auténticos", debido a que las industrias culturales les construyen hábilmente características que rompen con las ataduras sociales. $\mathrm{Al}$ adquirirlos, ya sea en tiendas especializadas o internet, se fortalece la percepción de que se está en otra instancia distinta, en otro mundo (oscuro) donde pueden re-significar las características de estos productos y expresarlas de nueva cuenta con un sentido alternativo.

Al cuestionárseles esta contradicción entre la autonomía y el consumo, sus posiciones coincidieron en la distinción entre ser consumidor (el que compra inteligentemente) y consumista (el alienado atrapado por la publicidad), para fijar así una posición ante la sociedad de consumo, aunque en realidad no escapan a las diversas tendencias del mercado, que cambian constantemente, sobre todo, en el ámbito discográfico y cinematográfico.

Lo gótico se convirtió en un gran negocio de las industrias culturales y esto provoca, para quien no esté familiarizado con el movimiento, que califique por igual todo lo que se le ofrece: Marylin Manson puede ser tan gótico como Hocico o Anabantha, grupos realmente representativos para la escena oscura mexicana. 
Más que un regalo (o un "regalo gratis", por mencionar ese pleonasmo acuñado por los consultores de marketing), la identidad es una condena a realizar trabajos forzados de por vida. Para los fabricantes de ávidos e infatigables consumidores y los vendedores de bienes de consumo es también una fuente inagotable de ganancias, más copiosa cuanto más utilizada (Bauman, 2007: 151).

Para los góticos que llevan más tiempo en el movimiento esto significa una intromisión del expansionismo capitalista en sus círculos, y una manera de resistir según su manera de pensar - es adquirir o intercambiar discos, libros u otros productos de manera interpersonal, o bien, en tianguis como "El Chopo" (Ciudad de México) y no en centros comerciales.

Por esta razón el movimiento gótico llegó ya a la tercera década de existencia sin visos de entrar en decadencia musical o literaria, gracias al sentido alternativo que se le otorga a los productos constantemente re-posicionados según las tendencias. En México, el número de bandas góticas ha crecido enormemente y esto ocasiona que, en las tiendas de discos, lo gótico aparezca como un género con espacios específicos para su venta en los anaqueles.

Estos jóvenes representan un auto-determinismo, que intenta resistirse al consumismo, la lógica de mercado, los medios masivos de comunicación, pero que los confronta frente a cierto tipo de productos que finalmente adquieren según sus intereses. De esta manera, las figuras del inadaptado, el héroe romántico o el solitario, que se identifican con la nostalgia, el vacío, la decadencia o el terror, están presentes en los discos, libros, videos, muñecos, vestimentas o accesorios que convierten a estos jóvenes en seres distintos.

El mercado oscuro sigue creciendo y con ello un tipo de consumo que se escuda en la inteligencia y adquiere permanentemente ideas, tendencias, valores u objetos que les convierten en testigos oscuros y siniestros de la vida social. Las industrias culturales están muy al tanto de estos aspectos y mediante la mercadotecnia y la publicidad seguirán edificando el lado oscuro de la vida social y los productos distintivos para instalarse en ellas.

\section{Notas}

1 Ver en, http://www.detribusurbanas.com/tipos/5goticos.

${ }^{2}$ Para mayor información se puede visitar la página http:// vanguardiaeditores.com/gotica/home/divan.php.

${ }^{3}$ Joven maya tsotsil oriundo del municipio de Chenalhó. Es uno de los personajes más reconocidos dentro del movimiento gótico en San Cristóbal de Las Casas, Chiapas.

4 Es una de las integrantes más significativas del movimiento en San Cristóbal. Ella elaboró la tesis El suicidio en el imaginario colectivo de los jóvenes góticos en San Cristóbal de Las Casas, con la que obtuvo en el 2011 el título de Licenciada en Comunicación Intercultural en la Universidad Intercultural de Chiapas.

${ }^{5}$ Es egresado de la Licenciatura en Antropología de la Facultad de Ciencias Sociales de la Universidad Autónoma de Chiapas. Actualmente trabaja una tesis sobre el papel del miedo en la socialización de los niños.

${ }^{6}$ Término que emplean estos jóvenes para referirse a los "imitadores", a aquellos que creen formar parte de la comunidad oscura, pero no comprenden los diversos significados que tiene este estilo de vida.

${ }^{7}$ Autores como Paul Aries, los definen como seres que "coquetean" con el ocultismo y cuya transformación como seres oscuros no es necesariamente maligna, sino una forma lúdica de distanciarse de los patrones religiosos tradicionales.

${ }^{8}$ El inglés Aleister Crowley es considerado el padre del satanismo moderno y se distinguió por restaurar algunas tradiciones paganas. Se dedicó a recabar ritos provenientes de diversas culturas, sobre todo de la egipcia, y fue plasmándolos en obras como "Magick", 
que influyeron notablemente en diversas sectas en el siglo pasado.

9 Integrante del equipo de Ecumenismo y Diálogo Interreligioso del Observatorio Pastoral del CELAM. Para mayor información ver en, http://www.celam.org/ observatorio_pas/programa6.php.

${ }^{10}$ Sinónimo de amplificador.

"Venom (1982). Album Black Metal. Canción "Black metal”. Para mayor información visitar la página http:// www.elportaldelmetal.com/traduccion/black-metalvenom.

${ }^{12}$ Christian Death se formó en 1979 en Los Ángeles, California, y fue encabezado por Rozz Williams, quien se distinguió por ofrecer conciertos apoyados con elementos teatrales en los que se criticaba principalmente a las religiones cristianas.

${ }^{13}$ Es originaria del Distrito Federal. Ella perteneció al grupo Vía Dolorosa.

14 Egresada de la Licenciatura en Comunicación Intercultural de la Universidad Intercultural de Chiapas, de la generación 2008-2012.

\section{Bibliografía}

Aries, Paul (2005), "Culto generacional”, en Revista Proceso, Edición Especial, núm. 18.

Augé, Marc (2008), Los no lugares. Espacios del anonimato, Barcelona: Editorial Gedisa.
Bauman, Zygmunt (2007), Identidad, Buenos Aires: Losada.

Bauman, Zygmunt (2007), Vida de consumo, México: Fondo de Cultura Económica.

Bolaños, Luis (2011), La elaboración de la identidad gótica en San Cristóbal de Las Casas, Chiapas. Universidad de Ciencias y Artes de Chiapas. Centro de Estudios Superiores de México y Centroamérica. México.

Escribano, Marisa y Carrera, Mauricio (2007), Soy diferente: Emos, darketos y otras tribus urbanas, México: Diana.

Fuentes Rodríguez, César (2007), Mundo Gótico, Barcelona: Quarentena Ediciones.

García Canclini, Néstor (2007), Lectores, espectadores e internautas, México: Gedisa Editorial.

Heath, Joseph y Potter, Andrew (2005), Rebelarse vende. El negocio de la contracultura, Madrid: Taurus.

Mafessoli, Michel (2004), El tiempo de las tribus. El ocaso del individualismo en las sociedades posmodernas, México: Siglo XXI.

Molina, Ignacio (2009), Tribus urbanas. Manual para comprender las nuevas subculturas juveniles, Buenos Aires: Kier.

Urteaga, Maritza (1998), Por los territorios del rock. Identidades juveniles y rock mexicano. Centro de Investigación y Estudios Sobre Juventud, Colección Joven, núm. 3, México: Coedición con el Consejo Nacional para la Cultura y las Artes. 
Figura 1. Onésimo Guzmán Arias: Arte oscuro

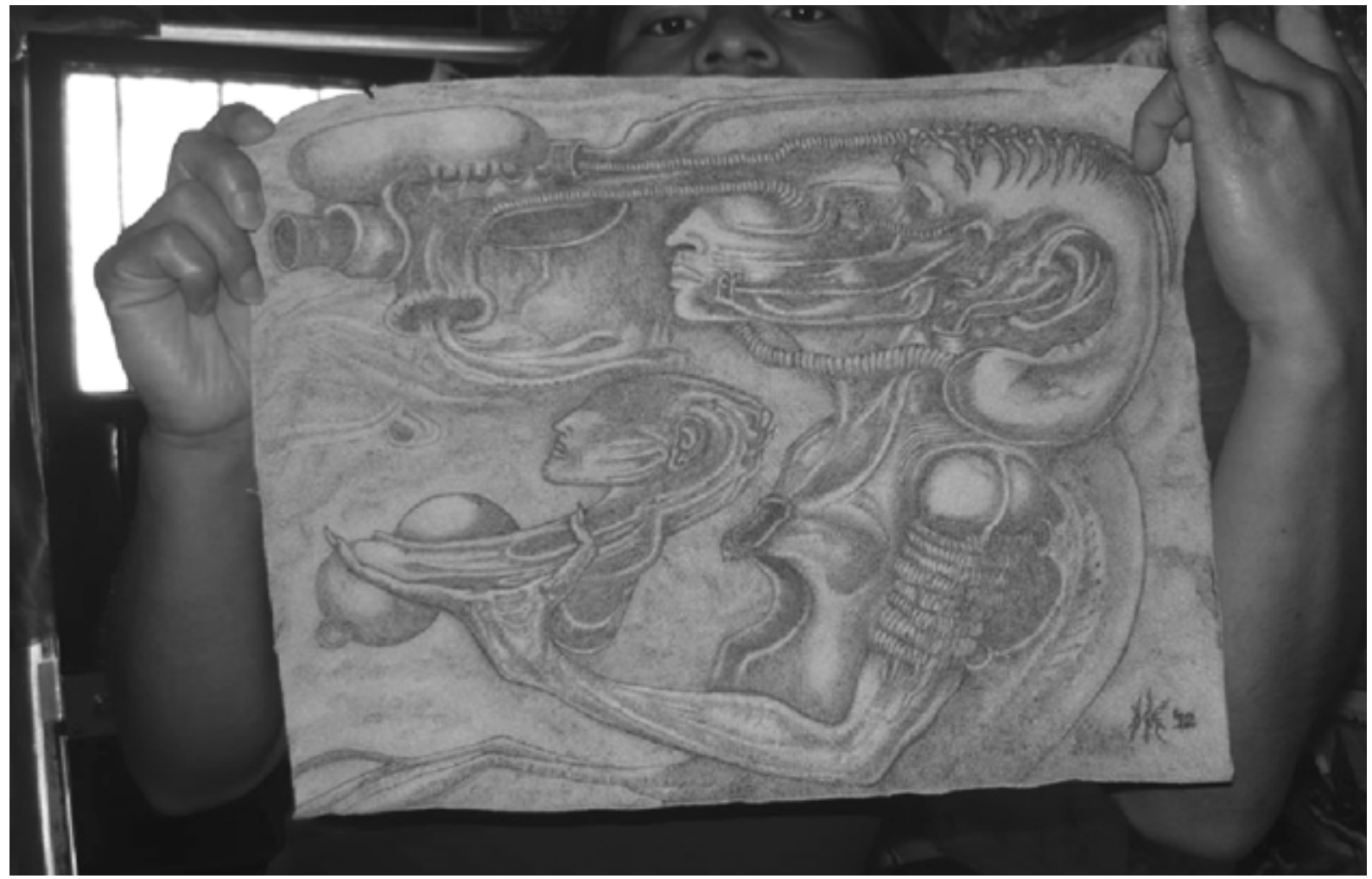

Fuente: Perfil de Facebook del entrevistado 
Figura 2. Eventos del movimiento oscuro en las redes sociales

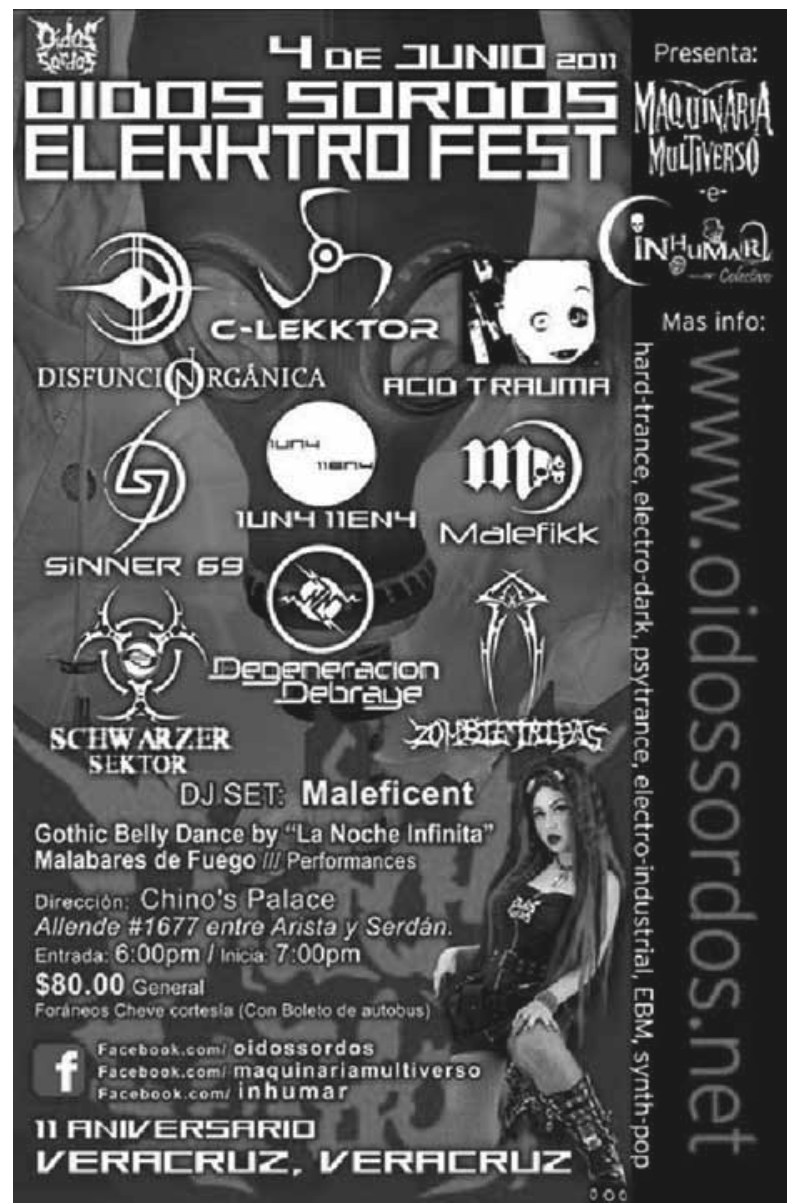

Fuente: Facebook.com/oídos sordos.
Figura 3. El Black metal: entre lo sobrenatural y la condición humana

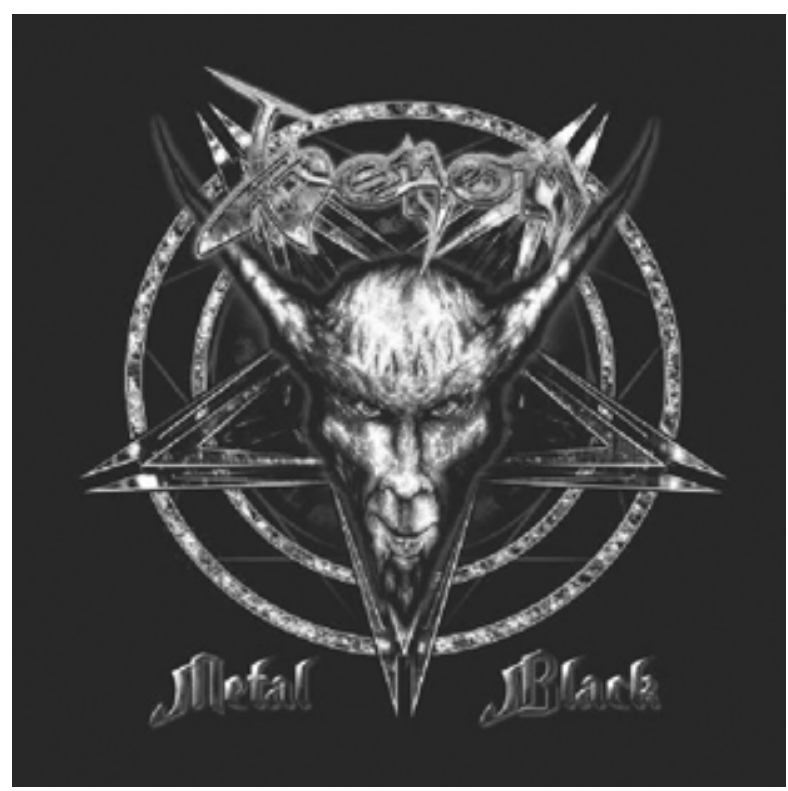

Fuente: http://counterattack.dir.bg/smf_bg_com/covers cd/2006/Venom-Metal\%20Black.jpg. 
Figura 4. Vampiros metrosexualizados

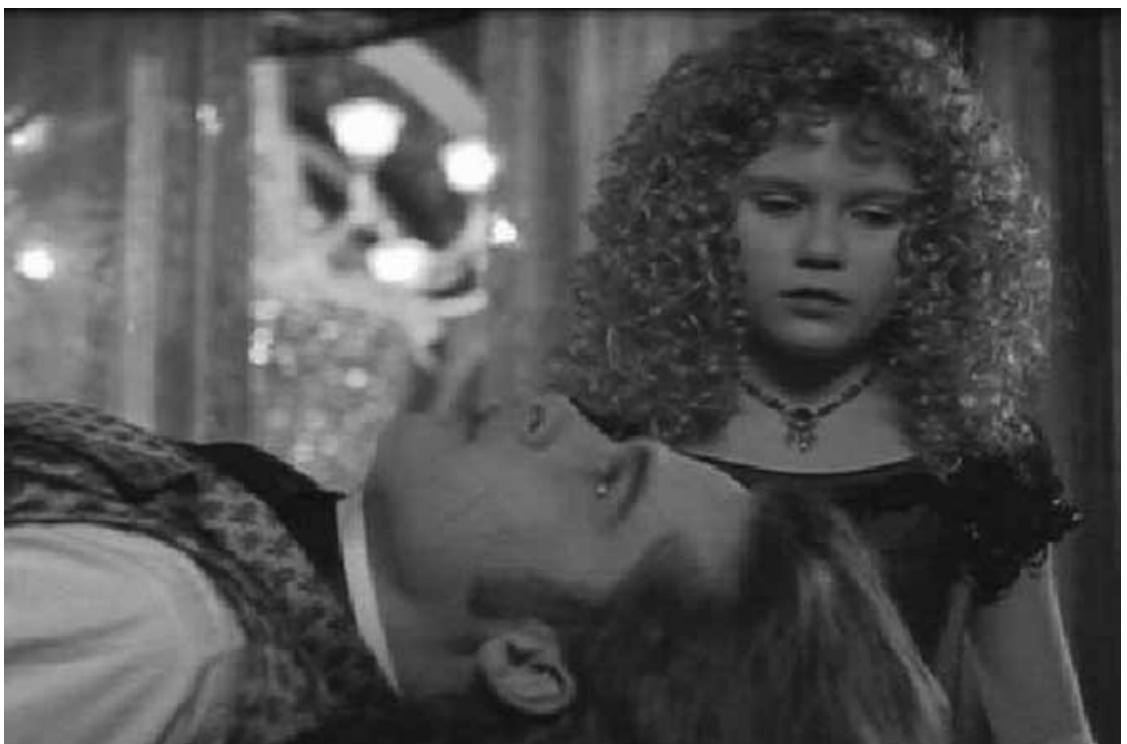

Fuente: http://www.trinitysnape.blogspot.com.

Figura 5. Marilyn Manson: El gran mercado oscuro

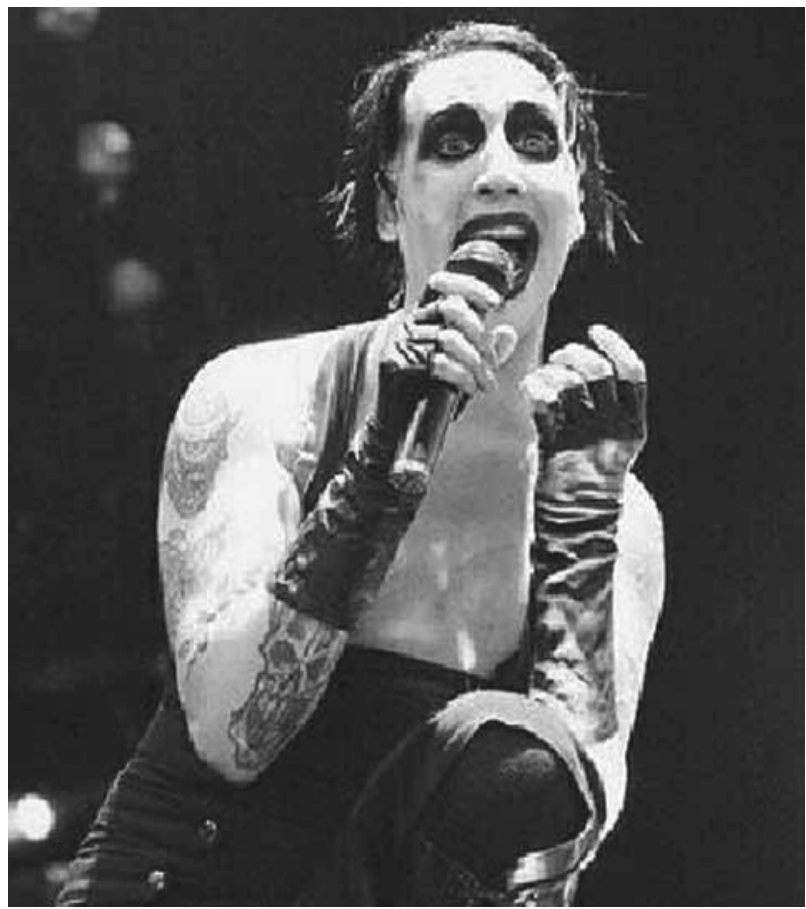

Fuente: http://www.usonica.com/images/2007/05/manson-marilyn-photo. 